\title{
Gay sex crimes in Europe 1500-1790
}

Lesley Smith

Curator, Tutbury Castle, Tutbury, UK

\section{Correspondence to} Ms Lesley Smith, Tutbury Castle, Tutbury Staffordshire DE13 9JF, UK; info@tutburycastle.com

Received 9 August 2012 Accepted 9 August 2012

\section{Terminology}

The sexual behaviour of people has always been of interest to others throughout history and many forms of sexual activity have been the subject of control by the established church or state. What is interesting though is the response at different times to the same sex act, which can range from a public round of applause to the death sentence.

The term sodomy originally had a different meaning from today. Over many centuries the word described criminal behaviour when individuals were involved in sexual activity simply for pleasure and not for what was considered the only decent and proper form: that of procreation. Whilst same-sex activity between men was, according to records, the largest and commonest use of the term sodomy, cases of sex with animals, oral and anal sex between men and women, and even masturbation were regarded as crimes of sodomy. In fact, any sexual activity that could be viewed as unnatural and therefore undesirable to state and church could be classified thus.

Ecclesiastical courts, as well as criminal courts, were involved in trials and prosecutions. It is hardly surprising that the links to witchcraft and sexual deviance were closely aligned in the centuries and places when witch hunting was of national or regional interest across Europe, and there are clear rises and falls in court statistics.

It was not until the Georgians came to the throne of England that the term sodomy came to mean sex acts between men exclusively and that did not necessarily include penetration or indeed ejaculation.

\section{Homosexuality}

During the Renaissance it was a dangerous matter for a man to be caught having sex with another man, and many court records still exist in mainland Europe as well as England to testify to this. Italy was, without question, the place to find other homosexual men as the state seems to have turned a blind eye on most instances, except the most blatant cases. Italy became known as a place for sexual adventure and that may have been one of the attractions of the Grand Tour embarked upon by many wealthy young men.

Between the mid-16th and mid-17th centuries, Geneva executed 30 men for same-sex sodomy and Paris 80 ; the Dutch seem to have been on some form of witch hunt in the mid-18th century, for in a 50 -year period some 269 sodomites were executed. It is also possible that some of the prosecutors and magistrates may have felt themselves to be on a mission, perhaps a holy mission, and sought out homosexuals vigorously and then punished them brutally. The idea of public punishment acting as a deterrent was firmly entrenched in the legal systems of Europe including the British Isles.

If the numbers are not shocking enough for the modern reader, then the types of death most certainly will be. Having stones tied to them and thrown into a river was a common method, as was burning at the stake. The one seems to represent a cleansing and the other the old mediaeval belief that the intense pain of burning would cleanse the soul of sin. Some men were merely banished to take what were considered their unnatural habits elsewhere and cleanse the streets of their presence. There are some who were merely chained to a large stone for a year which was humiliating, but it is likely that the individuals concerned survived their punishment.

Court records usually show details of the profession of the individuals being tried, from bakers to soldiers to surgeons (the barber kind), and a description of the form of sodomy they engaged in by witness or confession. Frottage, intercrual (a type of non-penetrative) sex, masturbation and fondling appear regularly, along with oral sex and sometimes the phrase "oral sex without ejaculation", which could lead to execution by drowning. 
There is a particularly distressing case I came across in my research in which a young boy was taken by a man as a servant and was sexually abused in such a brutal manner that an innkeeper heard the boy crying and found him weeping alone, so damaged that he was unable to walk. The kind innkeeper carried the boy in his arms to a local doctor and the master was later arrested. The master was tried, found guilty and burned at the stake publicly. The boy was also tried and the court decided that he shared the guilt as he had not reported the abuse to the authorities even though he was terrified to do so. The boy was whipped and then thrown on to his dead master's body, which was still smouldering in the hot ashes. Despite the professional objectivity one tries to retain when researching such stories, sometimes the imagery remains in the memory for some time.

The courts often prosecuted abused or unwilling individuals for not reporting offences. A man could be found guilty of sodomy even if he had been raped and was too embarrassed to report the crime. There are still men who feel unable to report rape today for the same reason. The courts were largely unsympathetic and viewed the abused as culpable if they did not report such events.

The level of brutality one can find in sentencing proves that the church and state were absolutely determined during some periods of history to stamp out any form of sexual activity unless it was heterosexual and within the confines of marriage or contract.

\section{Lesbianism}

Lesbian sexuality hardly appears in the records but can be found. A widow from Geneva seduced two young servant girls by fondling one in her bed and having the other girl watch events whilst the widow talked of erotic adventures. This resulted in the comparatively lenient sentence for the widow of banishment. The girls were not punished as they had come forward and demonstrated they been "scandalisd" by these events.

It seems that lesbianism was not considered such a threat to society, although there are cases recorded of executions. There were a number of lesbian trials in Holland in the 18th century, some of which are both interesting and amusing. In one case there appear to be a very large number of witnesses, and it transpires that almost the entire village took turns to watch the women through a hole in a neighbour's wall over a number of hours. Strap-on dildos and tribades are mentioned in records, together with oral sex, fondling and frottage.

There are also queens who are thought to have been involved in lesbian relationships. Marie Antoinette of France, and both the Stuart sisters, Queen Mary and Queen Anne of England, were the source of considerable gossip at court and beyond for their female fancies.
Hester Thrale Piozzi, who was "mistress" to the lexicographer, Dr Samuel Johnson, and an impressive academic herself, wrote scathingly of Marie Antoinette as a monster and Sapphist. Hester Thrale was involved in a major scandal herself by marrying her daughter's Catholic Italian music teacher, Piozzi. Now that really did cause a stir and she was not accepted into polite society for some time because of it.

The most convincing evidence of a lesbian monarch in the period I am writing about was Queen Christina of Sweden who, in the mid-17th century, spent most of her time dressed as a man and refused to marry despite considerable pressure from the Swedish government, who were alarmed at the prospect of there being no heir to the throne, as well as Queen Christina's choice of clothes. Christina abdicated after a few years on the throne, no doubt seeking her sexual pleasures without the restraints associated with being a monarch.

\section{Future articles}

The next article in this series will consider "Rape".

\section{About the author}

Lesley Smith is currently a postgraduate student in the Centre for the History of Medicine of the University of Birmingham, where she is developing a $\mathrm{PhD}$ in obstetrics and gynaecology in early modern Britain. She holds an honorary degree for 'services to history'. She makes 200-300 public appearances a year and also works as a TV historian in the UK and abroad including the USA. Lesley is also Curator of Tutbury Castle in Staffordshire and is a member of the Society of Apothecaries of London and the Society of Medical Writers. She has recently been appointed a Fellow of the Society of Antiquaries of Scotland.

Acknowledgement The author would like to thank Dr G Williams, British Museum, London, UK for his help and advice.

\section{Competing interests None.}

Provenance and peer review Commissioned; internally peer reviewed.

\section{Bibliography}

1 Gowing L. Common Bodies: Women, Touch and Power in Seventeenth-Century England. London, UK: Yale University Press, 2003.

2 Haynes A. Sex in Elizabethan England. Stroud, UK: Sutton Publishing (The History Press), 2006.

3 Gaskill M. Witchfinders: A Seventeenth-Century English Tragedy. London, UK: John Murray Publishing, 2006.

4 Brown K. The Pox: The Life and Near Death of a Very Social Disease. Stroud, UK: Sutton Publishing, 2006.

5 Naphy W. Sex Crimes: From Renaissance to Enlightenment. Stroud, UK: Tempus Publishing (The History Press), 2004. 